\title{
Alternative foods for the multicoloured Asian lady beetle Harmonia axyridis (Coleoptera: Coccinellidae)
}

\author{
Nick BERKVENS ${ }^{1}$, CARMEN LANDUYT $^{1}$, KOEN DEFORCE $^{2}$, DirK BERKVENS ${ }^{3,4}$, LUC TIRRY $^{1}$ \\ and PATRICK DE CLERCQ ${ }^{1 *}$
}

\begin{abstract}
${ }^{1}$ Laboratory of Agrozoology, Department of Crop Protection, Faculty of Bioscience Engineering, Ghent University, Coupure Links 653, B-9000 Ghent, Belgium; e-mails: Nick.Berkvens@UGent.be; carmenlanduyt@yahoo.co.uk; Luc.Tirry@UGent.be; Patrick.DeClercq@UGent.be

${ }^{2}$ Flemish Heritage Institute, Koning Albert II laan 19 bus 5, B-1210 Brussels, Belgium; e-mail: koen.deforce@rwo.vlaanderen.be ${ }^{3}$ Department of Animal Health, Prince Leopold Institute of Tropical Medicine, Nationalestraat 155, B-2000 Antwerp, Belgium; e-mail: dberkvens@itg.be

${ }^{4}$ Department of Animal Production, Faculty of Bioscience Engineering, Ghent University, Coupure Links 653, B-9000 Ghent, Belgium
\end{abstract}

Key words. Coccinellidae, Harmonia axyridis, invasive species, development, frugivory, fungivory, pollinivory, reproduction

\begin{abstract}
The multicoloured Asian lady beetle Harmonia axyridis (Coleoptera: Coccinellidae) may potentially exploit a range of "alternative" food sources. The nutritional value of three common non-prey food groups, i.e. fruit, fungi and pollen, is examined in this study. Development, reproduction and survival of the species were assessed in the laboratory on diets of apple, pear and raspberries and the fungi Oidium lycopersicum, Botrytis cinerea, Sclerotinia sclerotiorum and Rhizoctonia solani. When fed exclusively on these foods this ladybird failed to complete its development or reproduce. However, larval and adult survival was prolonged by 4 to 8 days and 55 to 67 days, respectively, when fruit was offered compared with only water. During a field study H. axyridis adults were collected monthly from March to October at two locations near Ghent, Belgium. Gut analysis demonstrated that, despite the continued presence of aphids, over $90 \%$ of all the adults collected contained pollen throughout the year. The pollen belonged to 53 different pollen types. Monthly average numbers of pollen grains in the gut varied from 5 to 233 grains. In contrast, there were about 35,000 grains in the guts of $\mathrm{H}$. axyridis females that successfully developed and reproduced in the laboratory on diet that consisted of only pollen. This suggests that in the field in the majority of cases pollinivory mainly only provided complementary nutrients for this coccinellid. The use of alternative non-prey foods like pollen and fruit may play a role in sustaining populations of this coccinellid at times when the optimal prey is absent.
\end{abstract}

\section{INTRODUCTION}

Harmonia axyridis (Pallas) (Coleoptera: Coccinellidae) is indigenous to central and eastern Asia (Coderre et al., 1995; Nalepa et al., 1996; Koch, 2003; Brown et al., 2008). The species was released as a biological control agent of aphid and coccid pests and has become established in parts of the Americas, Europe and Africa (Katsoyannos et al., 1997; Koch, 2003; Koch et al., 2006; Coutanceau, 2006; Brown et al., 2008). Several studies have indicated the potential risks of this invasive insect, including threats to native biodiversity, fruit and wine production and human health (Brown \& Miller, 1998; Colunga \& Gage, 1998; Yarbourgh et al., 1999; Huelsman et al., 2002; Koch, 2003; Galvan et al., 2008).

Harmonia axyridis is highly polyphagous. It mainly consumes aphids, but can also feed on Tetranychidae, Psyllidae, Coccoidea, Chrysomelidae, Curculionidae and Lepidoptera, and is an intraguild predator (Tedders \& Schaeffer, 1994; Hodek \& Honěk, 1996; Koch, 2003; Pell et al., 2008). This species also exploits plant foods. Several studies have recorded $H$. axyridis feeding on fruit in autumn (e.g. pumpkins, apples, raspberries and grapes)
(Koch et al., 2004; Galvan et al., 2008; pers. obs.). Adults of Coccinella septempunctata L. (Coleoptera: Coccinellidae) also feed on pears and peaches, and Adalia bipunctata (L.) (Coleoptera: Coccinellidae) on cherries and plums (Hodek \& Honěk, 1996). Furthermore, Berkvens et al. (2008) demonstrated that in the laboratory some individuals can complete development and reproduce on pollen alone. Moser et al. (2008) observed H. axyridis larvae consuming leaf tissue. Although polyphagous coccinellids lack the morphological adaptations to their mouthparts, which facilitate the collection of spores and feeding on fungi (like comb and rake-like structures or a series of spines or teeth to scrape spores from fungal material), gut analyses have illustrated that fungal spores make up an important part of the diet of a number of aphidophagous coccinellids (Lundgren, 2009). Little is known about fungivory in $H$. axyridis. Some non-prey foods have been categorized as alternative foods for coccinellids, either because they contain supplementary nutrients that sustain the predators at times when there is little or no nutritionally optimal prey at hand, or because they form part of an optimal mixed diet (Kiman \& Year-

\footnotetext{
* Corresponding author; e-mail: Patrick.DeClercq@UGent.be
} 
gan, 1985; Hodek \& Honěk, 1996; Jørgenson \& Toft, 1997; Patt et al., 2003). Adriaens et al. (2008) demonstrated that $H$. axyridis can persist in a wide range of habitats suggesting that this species is most likely exposed to a variety of alternative foods.

In order to obtain a better insight into the range of "alternative" non-prey food sources exploited by $H$. axyridis, its survival, development and reproductive performance when fed several types of fruit and fungi in the laboratory was determined. Building on the laboratory observations of Berkvens et al. (2008) that some $H$. axyridis are able to complete development and reproduce when they are fed solely on pollen, a second part of the present study focused on the exploitation of pollen by $H$. axyridis in the field.

\section{MATERIAL AND METHODS}

\section{Fitness of $\boldsymbol{H}$. axyridis fed on fruit and fungi}

A non-melanic population of $H$. axyridis was established at the Laboratory of Agrozoology of Ghent University, Belgium. In June 2008, approximately 100 non-melanic adults were collected in a recreational park in Ghent, Belgium. These adults were then reared in the laboratory at $23 \pm 1{ }^{\circ} \mathrm{C}, 65 \pm 5 \% \mathrm{RH}$ and a 16L : 8D photoperiod and fed frozen E. kuehniella eggs, as described in De Clercq et al. (2003). Individuals of the $3^{\text {rd }}$ to $9^{\text {th }}$ generation of the non-melanic population were used in the experiments.

Development, reproduction and survival of this species fed a range of different foods were determined. Three types of fruit were tested: apple Malus domestica L. (cv. Jonagold) (Rosales: Rosaceae), pear Pyrus communis L. (cv. Confrence) (Rosales: Rosaceae) and raspberry Rubus idaeus L. (Rosales: Rosaceae). The fruit was offered as fresh slices (about $1 \mathrm{~cm}^{3}$ ) of the whole fruit. Further, several fungi were also offered as food: Oidium lycopersicum Cooke \& Mass, Botrytis cinerea Pers. Ex. FR., Sclerotinia sclerotiorum (Lib.) De Bary and Rhizoctonia solani J.G. Khn. Oidium lycopersicum was obtained from naturally infested tomato plants. It was cultured by contaminating noninfested tomato plants in a growth chamber at $23^{\circ} \mathrm{C}$. During the experiments, infested tomato leaves were offered to the predator. The leaf petioles were placed in $1.5 \mathrm{ml}$ Eppendorf tubes filled with water and sealed with Parafilm to keep them fresh. Cultures of $B$. cinerea, $S$. sclerotiorum and $R$. solani on Potato Dextrose Agar (PDA) medium were obtained from the Laboratory of Phytopathology at Ghent University, Belgium. The mycelium and fruiting bodies of these fungi were offered together with the PDA-medium they were cultured on. Controls were included in which the individuals were fed only PDAmedium, uncontaminated tomato leaves, E. kuehniella eggs and no food. All food types were provided ad libitum. A moist paper plug fitted into a $1.5 \mathrm{~cm}$ plastic dish was the water source in each treatment. Food and water were renewed every two days, with the exception of the raspberries, which were replaced every day.

In order to study immature development on the different foods, 40 newly hatched first instar larvae from the non-melanic stock culture were transferred to individual Petri dishes (diameter $9 \mathrm{~cm}$ ) and offered one of the food sources. Survival and development were monitored daily. Only when fed E. kuehniella eggs, did immatures complete development; the resulting adults were used to test the reproductive capacity of $H$. axyridis fed on E. kuehniella eggs. For all other food types and controls, 40 newly emerged adults from the stock culture fed on E. kuehniella were used. Two days after emergence, the adults were mated in a Petri dish (diameter $9 \mathrm{~cm}$ ) and one of the food types and a water source provided. The dishes were checked daily for mortality and oviposition. Eggs were collected, counted and then kept in a Petri dish for 5 days, after which the number that had hatched was determined. The reproductive output and longevity were monitored over 80 and 140 days, respectively. As it was unavailable the fungus $S$. sclerotiorum was not included in this study. All experiments were conducted in incubators held at $23 \pm 1{ }^{\circ} \mathrm{C}, 65 \pm 5 \% \mathrm{RH}$ and a $16 \mathrm{~L}: 8 \mathrm{D}$ photoperiod.

\section{Exploitation of pollen by $\boldsymbol{H}$. axyridis in the field}

A field study was conducted to determine the exploitation of pollen by $H$. axyridis throughout the year. This was done by analyzing the gut contents of field collected adults. Harmonia axyridis adults were collected at 2 locations in Ghent, the recreational park "Groene Vallei" and a nature reserve "Bourgoyen". Adults were collected once a month from August 2008 to July 2009. The plant species on which each individual was collected was recorded. In October 2008, adults were collected during migration to overwintering sites near both locations. From November to February no individuals were collected as they were in hibernation. Collected insects were immediately placed in ethanol (Disinfectol, $5 \%$ ether) and transferred to a freezer at $-18^{\circ} \mathrm{C}$. The digestive tract was dissected and the contents were acetolysed according to the method described by Erdtman (1960). The resulting residue was examined under a microscope and pollen grains were identified and quantified. Identification and nomenclature of the pollen types is based on Beug (2004) and Punt et al. (1976-2003). The gut contents of 10 adults from each location were examined. As a reference, individuals from the laboratory stock population were fed on frozen moist honeybee pollen from the first instar up to three weeks into the adult stage (see Berkvens et al., 2008). The gut content of 10 of the resulting adults was acetolysed and pollen grains quantified as described above.

\section{Statistical analysis}

All statistical analyses in this study were performed using Stata/SE 9.2 (StataCorp, 2005). None of the data obtained followed a normal distribution. For this reason a generalized model was used. The link function and the error distribution were chosen depending on the nature of the data. A generalized linear model was used for countable data (Poisson distribution if applicable and negative binomial distribution in cases of overdispersion), while a logistic regression was used when the data were binary (e.g. mortality). If appropriate, the statistical analysis started with a saturated model and interactions and nonsignificant main factors were dropped at a significance level of 0.05. Likelihood ratios were used to assure model fit and the most parsimonious model is reported in the study (McCullagh \& Nelder, 1989).

\section{RESULTS}

\section{Fitness of $\boldsymbol{H}$. axyridis fed fruit and fungi}

When fed E. kuehniella eggs, 37 of the $40 \mathrm{H}$. axyridis individuals reached the adult stage after $19.4 \pm 0.75$ days (mean $\pm \mathrm{SE}$ ). On all other diets the majority of the individuals died during the first instar. Only when fed $R$. solani and apple did 1 and 6 individuals, respectively, develop to the second instar. Overall, larvae fed only fruit survived longer than those fed other diets (Fig. 1). An analysis based on a Poisson regression revealed that larval survival was longest on apple ( $\mathrm{p} \leq 0.003$ compared to all other diets), followed by pear ( $\mathrm{p} \leq 0.042)$, raspberry $(\mathrm{p} \leq 0.042)$ and the PDA medium $(\mathrm{p} \leq 0.013)$. Survival on 


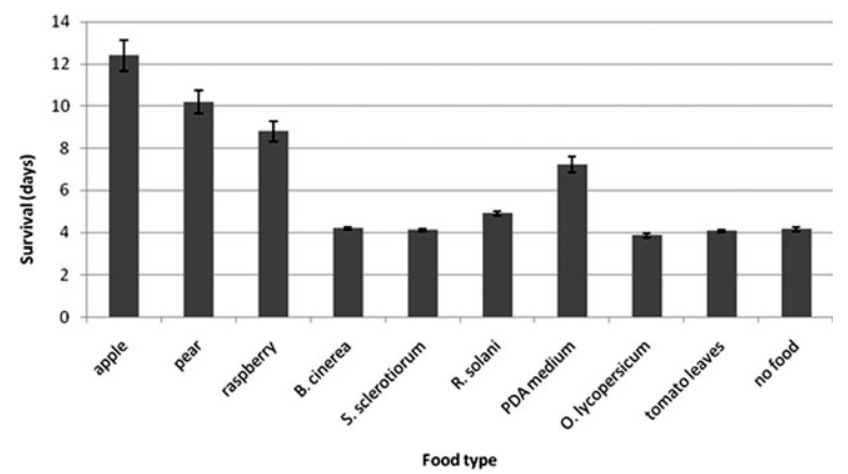

Fig. 1. The period of time (mean $\pm \mathrm{SE}$ ) for which first instar larvae $(\mathrm{n}=40)$ of $H$. axyridis survived when offered a diet of apple, pear, raspberry, B. cinerea, $S$. sclerotiorum, $R$. solani, $O$. lycopersicum, PDA medium, tomato leaves or no food. All larvae were supplied with water.

fungi, on non-infected tomato leaves and on water only did not differ, except for the longer survival time on $R$. solani than on $O$. lycopersicum $(\mathrm{p}=0.025)$.

Females oviposited only when fed eggs of $E$. kuehniella. During the 80 day monitoring period, females laid $1322.1 \pm 150.1$ eggs (mean \pm SE) of which $531.3 \pm$ 66.4 hatched. $H$. axyridis did not reproduce when fed any of the other diets. Also, longevity of adults was substantially affected by the diet (Fig. 2). Except for 16 of the 40 adults fed E. kuehniella eggs, all adults died on the other diets before the end of the 140 day monitoring period. A negative binomial regression revealed that adults lived longest on E. kuehniella eggs ( $\mathrm{p}<0.001$ compared to all other diets), followed by apple, pear and raspberry ( $p<$ $0.001)$. Longevity on pear was higher than on raspberry $(\mathrm{p}=0.001)$. Adults survived equally long on $B$. cinerea, $R$. solani, O. lycopersicum, uninfected tomato leaves and PDA medium. The longevity on the diets was greater than on water alone ( $\mathrm{p} \leq 0.001$ compared to other diets). There were no differences in longevity of males and females among diets.

\section{Exploitation of pollen by $\boldsymbol{H}$. axyridis in the field}

Pollen was found in the gut of $91 \%$ of the adults collected in the field. At both sampling sites, pollen was

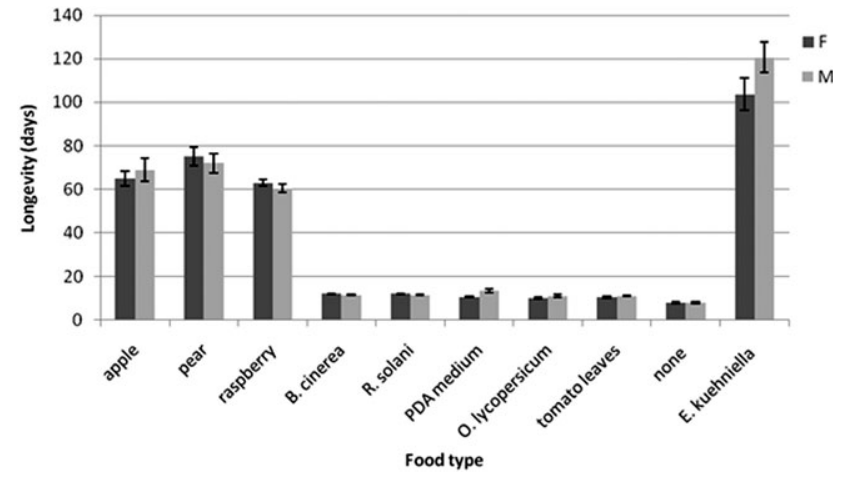

Fig. 2. The longevity (mean $\pm \mathrm{SE}$ ) of $H$. axyridis adults fed a diet of apple, pear, raspberry, B. cinerea, $R$. solani, O. lycopersicum, PDA medium, tomato leaves or no food. All adults were supplied with water. F - female, $\mathrm{M}$ - male. found throughout the sampling period (March to October) (Fig. 3). The total number of pollen grains found in the gut of $H$. axyridis ranged from $5.1 \pm 1.8$ grains at Bourgoyen in May to $233.1 \pm 125.3$ at the same location in March. The following pollen types were detected: Abies, Acer, Aesculus hippocastanum L., Alnus, Anthemis type, Apiaceae, Artemisia, Aster type, Asteraceae, Liguliflorae, Betula, Brassicaceae, Carpinus betulus L., Castanea sativa Mill., Cerealia undiff., Chelidonium majus L., Chenopodiaceae, Cornus sanguinea L., Corylus, Cyperaceae, Fabaceae, Fagus, Fallopia convolvulus L. type, Filipendula, Fraxinus, Galium type, Hedera helix L., Humulus type, Impatiens, Juglans, Ligustrum vulgare L., Lotus, Mentha type, Papaver rhoeas L. type, Pinus, Picea, Plantago lanceolata L., Plantago major/media L., Platanus orientalis L., Poaceae, Polygonum aviculare L. type, Populus, Quercus, Rosaceae undiff., Rumex acetosa L. type, Salix, Sambucus nigra L. type, Taxus, Tilia, Typha latifolia L., Ulmus, Urtica dioica L. type, Valeriana officinalis L. type and Zea mays L. Of the 53 identified pollen types, 39 were recorded in individuals collected at Bourgoyen and 46 at Groene Vallei. In the nature reserve Bourgoyen, the highest numbers of ingested pollen grains were recorded in March, April, June and August ( $\mathrm{p} \leq$ 0.011 compared to all other months). Pollen grain numbers in September were similar to those in April, but lower than in March, June and August $(p \leq 0.011)$. The lowest pollen grain numbers were recorded in May and July ( $\mathrm{p} \leq 0.044$ compared to all other months). Somewhat different trends were observed in the recreational park Groene Vallei. Here, the total number of pollen grains recorded was highest in March, August and September ( $p$ $\leq 0.037$ compared to all other months). The lowest pollen grain numbers were recorded in May, June and July ( $\mathrm{p} \leq$ 0.048 compared to all other months). Individuals collected at Bourgoyen had higher pollen grain numbers than those at Groene Vallei in March and June ( $p \leq 0.006)$, and marginally higher numbers in April $(\mathrm{p}=0.056)$. Adults collected in October had $3.9 \pm 1.6$ pollen grains in their guts.

Seven pollen types made up $93 \%$ of all pollen grains recorded in the gut analysis: Artemisia, Betula, Poaceae,

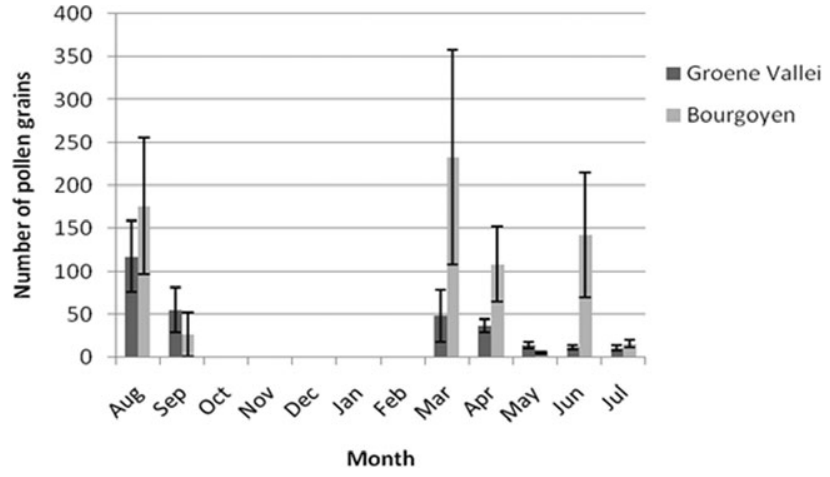

Fig. 3. Total number of pollen grains (mean $\pm \mathrm{SE}$ ) recorded in the guts of $H$. axyridis adults collected in different months at the recreational park "Groene Vallei" and nature reserve "Bourgoyen". 


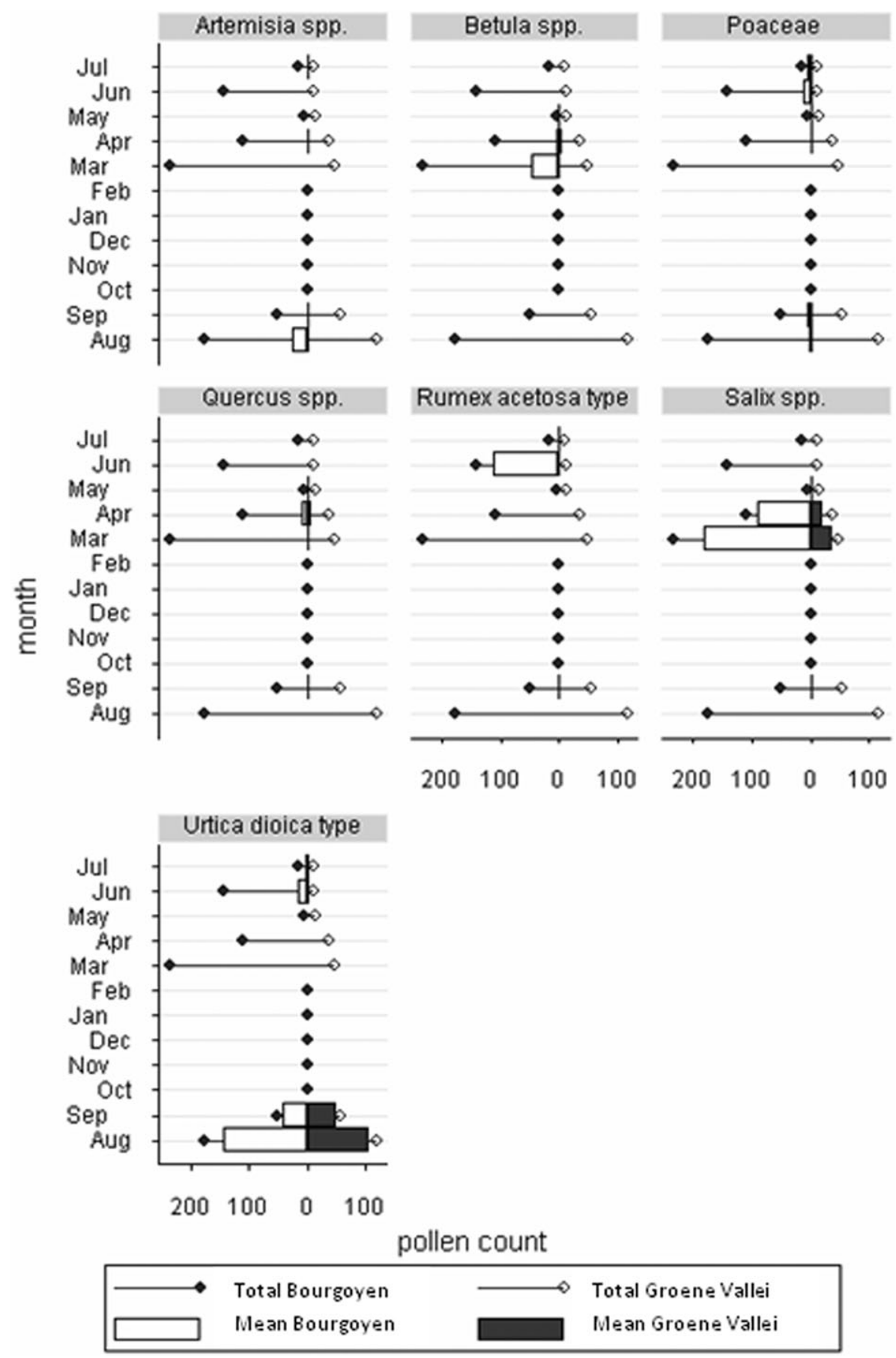

Fig. 4. Monthly mean numbers of grains of the seven most common types of pollen and the monthly mean total numbers of pollen grains recorded in the guts of $H$. axyridis adults collected at the nature reserve Bourgoyen and recreational park Groene Vallei from August 2008 to July 2009.

Quercus, R. acetosa type, Salix and U. dioica type. For all other pollen types, the mean number of pollen grains recorded never exceeded 5 grains per gut at either site at any time. In Fig. 4 the monthly mean total pollen grain numbers of the 7 most common pollen types and the monthly mean total number of pollen grains recorded for adults collected at both sites are depicted. There was no correlation between the plant species on which adults were collected and those yielding the main type of pollen grains found in their guts. Three-week-old adults that were reared in the laboratory exclusively on ad libitum amounts of pollen contained $34981.0 \pm 7261.4$ pollen grains.

\section{DISCUSSION}

Entomophagous arthropods, including coccinellids, regularly feed on a wide range of non-prey foods, including leaf tissue, fruit, fungi, pollen, seeds and honeydew (Hodek \& Honěk, 1996; Lundgren, 2009). Several of these non-prey foods, like pollen, fungi and fruit, are 
present in numerous (semi-) natural, agricultural and urban ecosystems throughout extended periods in the year. Exploiting non-prey food could thus be advantageous for polyphagous coccinellids when arthropod prey is scarce.

The fruit tested in this study were nutritionally inadequate to sustain development or reproduction in $H$. $a x y$ ridis. They can, however, be classified as an "alternative" food according to the definition of Hodek \& Honěk (1996), since they provide an energy source prolonging the survival of larvae and adults. Besides water, fruit predominantly contains carbohydrates. These are mainly energy-rich mono- or disaccharide sugars, with a small amount of polysaccharides like cellulose. To a much lesser extent fruit contains lipids, proteins, minerals and vitamins (Anonymus, 2009a). The high concentrations of mono- and disaccharide sugars in the fruit presented are the nutrients that probably resulted in the extended survival time of larvae and adults. These sugars are an important energy source for larvae and adults of ladybirds (Geyer, 1947; Pemberton \& Vandenberg, 1993). Although coccinellids are not capable of reproducing on sugars alone, fruit can improve or promote reproduction when only suboptimal prey is available (Lundgren, 2009). Adults of $H$. axyridis have frequently been observed feeding on fruit in autumn, a time when aphid prey often becomes scarce (Koch et al., 2004; Kovach, 2004; Galvan et al., 2008). Frugivory allows $H$. axyridis adults to obtain moisture, but also simple carbohydrates, which enhance winter survival (Koch et al., 2004), i.e. sugars are accumulated as glycogen for use during winter dormancy (Galvan et al., 2008). Galvan et al. (2008) found that survival of overwintering adults increased when they were fed a sucrose solution in the autumn compared to when they were provided with only water or no food. Some saccharides can also function as precursors of polyols, which act as cryoprotectants during winter (Watanabe, 2002; Galvan et al., 2008). In situations where more than 2 generations occur per year (e.g. southern Europe (Katsoyannos et al., 1997)), fruit may be available for larvae of $H$. axyridis to feed on from late summer onwards. However, larvae of this and other coccinellids have not yet been recorded as feeding on fruit.

Koch et al. (2004) observed that $H$. axyridis adults showed a clear preference for certain cultivars of fruit when given a choice, and hypothesized this was primarily related to differences in sugar content. These differences may also explain differences in survival among adults fed various types of fruit in this study. However, other nutritional factors (e.g. ripeness and acidity), physical characteristics (e.g. texture) and chemical characteristics (e.g. oxidation) may also determine the suitability of fruit as a food for $H$. axyridis. All the fruit was offered as fresh slices, which gave the insect direct access to the endocarp. Koch et al. (2004) found that $H$. axyridis adults only feed on undamaged fruit that have soft skins, like raspberries. Fruit with tougher skins, like pumpkins, apples and grapes, can only be consumed after the skin is bruised by another agent or by physiological processes (Galvan et al., 2008).

Fungi may offer certain nutrients to omnivorous insect predators, including carbohydrates, proteins, lipids and vitamins. However, because carbohydrates in fungi are primarily polysaccharide chitin and non-cellulosic $\beta$-1,3-glucans, $\alpha$-1,4-glucans and $\beta$-1,6-glucans, a unique set of enzymes are necessary to ensure that an organism can digest and metabolize these compounds (Cohen, 2004; Lundgren, 2009). In addition, fungi may possess a whole range of mycotoxins, non-nutritive secondary chemicals and structural defences protecting them from consumption (Lundgren, 2009). One or more of these factors appear to prevent $H$. axyridis from exploiting the fungi tested. Mycophagy in the field is recorded for other aphidophagous coccinellid like C. septempunctata, Scymnodes lividigaster (Mulsant) and Ceratomegilla notata (Laicharting) (Anderson, 1982; Triltsch, 1997, 1999; Ricci \& Ponti, 2005; Ricci et al., 2005). Triltsch (1997, 1999) and Ricci et al. (2005) found large amounts of Alternaria, Puccinia and Cladosporium spores in the gut of $C$. septempunctata during the pre-dormancy period in autumn and at the beginning of spring. It is hypothesized that these and other coccinellids rely on the fungi in autumn to build up nutrient reserves for dormancy and in the spring to obtain nutrition for dispersal and reproduction (Anderson, 1982; Triltsch, 1997, 1999). Adults of $H$. axyridis lived 3 to 4 days longer on the different fungi cultured on PDA-medium and on tomato leaves infected with $O$. lycopersicum compared to water only. However, since survival on the former diets did not differ from that on PDA medium or uninfected tomato leaves alone, the greater longevity may be attributed to nutrients in the medium or the leaf material, rather than in the fungi. Larvae of $H$. axyridis have been observed to feed on leaf tissue (Moser et al., 2008). In contrast, larvae offered $B$. cinerea, $S$. sclerotiorum and $R$. solani on PDA-medium had a lower survival than those offered PDA-medium alone, indicating detrimental effects of these fungi on larval viability.

The laboratory study by Berkvens et al. (2008) revealed that $H$. axyridis is capable of completing its development and reproducing on a diet of pollen. In the present field study, pollen was found in the gut of over $90 \%$ of the individuals sampled. In contrast, Triltsch (1997) reports that depending on the time of the year, only between 0 and $30 \%$ of all the C. septempunctata adults collected had pollen in their gut. The numbers of pollen grains recorded in the gut of $H$. axyridis were similar to or higher than those found in other beetle species that occasionally exploit pollen in the field. The western rootworm Diabrotica virgifera virgifera LeConte (Coleoptera: Chrysomelidae) is reported to have 40 to 120 pollen grains in its gut (Moeser \& Vidal, 2005) and the boll weevil Anthonomus grandis grandis (Boheman) (Coleoptera: Curculionidae) 2 to 25 pollen grains (Greenberg et al., 2007). The amount of pollen consumed by insects varies greatly among species depending on whether it is an essential food supporting development and/or reproduc- 
tion, as in female hoverflies (Hickman et al., 1995; Irvin et al., 1999), or merely a supplementary or alternative food sustaining survival for a short period of time, as in boll weevils (Greenberg et al., 2007). In the present study, fertile $H$. axyridis adults fed in the laboratory on only ad libitum quantities of pollen had about 35000 pollen grains in their gut, indicating that the majority of field collected $H$. axyridis adults had only ingested small amounts of pollen and that it may only be a supplementary source of nutrients for this coccinellid. However, two of the adults collected in April and August, contained substantially higher numbers of pollen (1631 and 1311 pollen grains), suggesting that pollen may be an ecologically relevant food source for $H$. axyridis. It is worth noting that aphids were abundantly available throughout the entire sampling period at both sites, from March when the coccinellids appeared up to September. This continuous presence of aphids possibly made the exploitation of pollen unnecessary throughout the study period. When aphids are absent or scarce, $H$. axyridis may consume higher numbers of pollen grains in order to sustain development or reproduction (Berkvens et al., 2008).

Except for Salix, the main pollen types found in the gut of $H$. axyridis are all from anemophilous (wind-pollinated) plants. Several of these, including Urtica, Quercus and Betula, are often frequented by $H$. axyridis (Adriaens et al., 2008). The pollen grains of entomophilous plants frequently visited by $H$. axyridis (e.g. Acer, Salix, Tilia, Crataegus and Prunus (Adriaens et al., 2008)), were also found in the gut of the beetles collected, but, except for Salix, in significantly lower quantities. This finding, together with the lack of a correlation between the plant on which the $H$. axyridis adults were collected and the predominant pollen type in their guts suggests that the majority of adults had not actively fed on the pollen, but ingested it unintentionally (e.g. pollen grains sticking on the body surface of prey). The acetolysis process did not allow us to determine to what degree the ingested pollen grains were digested.

It is not clear why few pollen grains were found in the guts of $H$. axyridis collected in May and July at both sites. Pollen grains of Salix spp. are usually still widely present in May, while in July pollen grains of Poaceae and $U$. dioica should be abundant (Anonymus, 2009b). In October the migrating adults contained very few pollen grains, which is probably because adults void their digestive tract in preparation for overwintering (Bale, 1987; Hodek \& Honek, 1996; Iperti \& Bertand, 2001).

In conclusion, the results of this study indicate that at times when various essential foods are absent, $H$. axyridis has other abundant alternative food sources that it can exploit for its survival, like pollen and fruit. In contrast, the fungi tested were of no use as a source of food for this coccinellid. Comparative studies on the ability of native lady beetles to use essential and alternative foods may further clarify the role of polyphagy in determining the invasiveness of $H$. axyridis.

AKNOWLEDGEMENTS. We are grateful to the members of the Laboratory for Agrozoology at Ghent University for their invaluable help in collecting lady beetles in the field. This study was funded by grant no. 53215 from the Institute for the Promotion of Innovation by Science and Technology in Flanders (IWT).

\section{REFERENCES}

Adriaens T., Gomez G.M.Y. \& Maes D. 2008: Invasion history, habitat preferences and phenology of the invasive ladybird Harmonia axyridis in Belgium. BioControl 53: 69-88.

ANDERSON J.M.E. 1982: Seasonal habitat utilization and food of the ladybirds Scymnode lividigaster (Mulsant) (Coleoptera: Coccinellidae). Aust. J. Zool. 30: 59-70.

Anonymus 2009a: The Composition of Selected Fruits. http://aggie-horticulture.tamu.edu/plantanswers/publications/n utrition/fruits.html, consulted last time 05/11/09.

Anonymus 2009b: Airallergy. Pollen Calender. http://airallergy. iph.fgov.be/sites/airallergy/all\%20pages/calendar.aspx, consulted last time 05/11/09.

BALE J.S. 1987: Insect cold hardiness: freezing and supercooling-an ecophysiological perspectlve. J. Insect Physiol. 33: 899-908.

Berkyens N., Bonte J., Berkvens D., Deforce K., Tirry L. \& De Clerce P. 2008: Pollen as an alternative food for Harmonia axyridis. BioControl 53: 201-210.

Beug H.-J. 2004: Leitfaden der Pollenbestimmung für Mitteleuropa und angrenzende Gebiete. Dr. Friedrich Pfeil, München, $542 \mathrm{pp}$.

Brown M.W. \& Miller S.S. 1998: Coccinellidae (Coleoptera) in apple orchards of eastern West Virginia and the impact of invasion by Harmonia axyridis. Entomol. News 109: 143-151.

Brown P.M.J., Adriaens T., Bathon H., Cuppen J., Goldarazena A., Hagg T., Kenis M., Klausnitzer B.E.M., Kovar I., Loomans A.J.M., Majerus M.E.N., Nedved O., Pedersen J., Rabitsch W., Roy H.E., Ternois V., Zakharov I.A. \& Roy D.B. 2008: Harmonia axyridis in Europe: spread and distribution of a non-native coccinellid. BioControl 53: 5-21.

Coderre D., Lucas É. \& Gagné I. 1995: The occurrence of Harmonia axyridis (Pallas) (Coleoptera: Coccinellidae) in Canada. Can. Entomol. 127: 609-611.

CoHen A.C. 2004: Insect Diets. Science and Technology. CRC Press, Boca Raton, FL, 324 pp.

Colunga-García M. \& Gage S.H. 1998: Arrival, establishment, and habitat use of the multicolored Asian lady beetle (Coleoptera: Coccinellidae) in a Michigan landscape. Environ. Entomol. 27: 1574-1580.

Coutanceau J.P. 2006: Harmonia axyridis (Pallas, 1773): une Coccinelle asiatique introduite, acclimaté et en extension en France. Bull. Soc. Entomol. Fr. 111: 395-401.

De Clercq P., Peeters I., Vergauwe G. \& Thas O. 2003: Interaction between Podisus maculiventris and Harmonia axyridis, two predators used in augmentative biological control in greenhouse crops. BioControl 48: 39-55.

ERDTMAN G. 1960: The acetolysis method, revised description. Sven. Botan. Tidskr. 54: 561-564.

Galvan T.L., Косн R.L. \& Hutchison W.D. 2008: Impact of fruit feeding on overwintering survival of the multicolored Asian lady beetle, and the ability of this insect and paper wasps to injure wine grape berries. Entomol. Exp. Appl. 12: 429-436.

Geyer J.W.C. 1974: A study of the biology and ecology of Exochomus flavipes Thumb. (Coccinellidae, Coleoptera). J. Entomol. Soc. Sth Afr. 9: 219-234.

Greenberg S.M., Jones G.D., Eischen F., Coleman R.J., AdamczyK J.J., Liu T.X. \& SÉtamou M. 2007: Survival of 
boll weevil (Coleoptera: Curculionidae) adults after feeding on pollens from various sources. J. Insect Sci. 14: 503-510.

Hickman J.M., Lövei G.L. \& Wratten S.D. 1995: Pollen feeding by adults of the hoverfly Melanostoma fasciatum (Diptera: Syrphidae). N. Z. J. Zool. 22: 387-392.

Hodek I. \& HonĚK A. 1996: Ecology of Coccinellidae. Kluwer Academic Publishers, Dordrecht, 464 pp.

Huelsman M.F., Kovach J., Jasinski J., Young C. \& Eisley B. 2002: Multicoloured Asian lady beetle (Harmonia axyridis) as a nuisance pest in households in Ohio. In Jones C., Zhai C. \& Robinson W.H. (eds): Proceedings of $4^{\text {th }}$ International Conference on Urban Pests, Charleston, South Carolina USA, July 7-10, 2002. Pocahontas Press, Blacksburg, VA, pp. $243-250$

IPERTi G. \& Bertand E. 2001: Hibernation of Harmonia axyridis (Coleoptera: Coccinellidae) in South-Eastern France. Acta Soc. Zool. Bohem. 65: 207-210.

Irvin N.A., Wratten S.D., Frampton C.M., Bowie M.H., Evans A.M. \& MoAR N.T. 1999: The phenology and pollen feeding of three hover fly (Diptera: Syrphidae) species in Canterbury, New Zealand. N. Z. J. Zool. 26: 105-115.

JøRGENSEN H.B. \& ToFT S. 1997: Role of granivory and insectivory in the life cycle of the carabid beetle, Amara similata. Ecol. Entomol. 22: 7-15.

Katsoyannos P., Kontodimas D.C., Stathas G.J. \& Tsartsalis C.T. 1997: Establishment of Harmonia axyridis on citrus and some data on its phenology in Greece. Phytoparasitica 25: 183-191.

Kiman Z.B. \& Yeargan K.V. 1985: Development and reproduction of the predator Orius insidiosus (Hemiptera: Anthocoridae) reared on diets of selected plant material and arthropod prey. Ann. Entomol. Soc. Am. 78: 464-467.

KocH R.L. 2003: The multicolored Asian lady beetle, Harmonia axyridis: a review of its biology, uses in biological control, and non-target impacts. J. Insect Sci. 3: 1-16.

Koch R.L., Burkness E.C., Wold Burkness S.J. \& Hutchison W.D. 2004: Phytophagous preferences of the multicolored Asian lady beetle (Coleoptera: Coccinellidae) from autumnriping fruit. J. Econ. Entomol. 97: 539-544.

Koch R.L., Venette R.C. \& Hutchison W.D. 2006: Invasions by Harmonia axyridis (Pallas) (Coleoptera: Coccinellidae) in the Western Hemisphere: Implications for South America. Neotrop. Entomol. 35: 421-434.

Kovach J. 2004: Impact of multicolored Asian lady beetles as a pest of fruit and people. Am. Entomol. 50: 159-161.

Lundgren J.G. 2009: Relationships of Natural Enemies and Non-Prey Foods. Progress in Biological Control 7. Springer Science + Buisness Media B.V., Lightning Source Ltd., Milton Keynes, 460 pp.

McCullagh P. \& Nelder J. 1989: Generalized Linear Models. Chapman \& Hall, London, 511 pp.
Moeser J. \& Vidal S. 2005: Nutritional resources used by the invasive maize pest Diabrotica virgifera virgifera in its new South-East-European distribution range. Entomol. Exp. Appl. 114: $55-63$

Moser S.E., Harwood J.D. \& Obrycki J.J. 2008: Larval feeding on Bt hybrid and non-Bt corn seedlings by Harmonia axyridis (Coleoptera: Coccinellidae) and Coleomegilla maculata (Coleoptera: Coccinellidae). Environ. Entomol. 37: 525-533.

Nalepa C.A., Kidd K.A. \& Ahlstrom K.R. 1996: Biology of Harmonia axyridis (Coleoptera: Coccinellidae) in winter aggregations. Ann. Entomol. Soc. Am. 89: 681-685.

Patt L.M., Wainright S.C., Hamilton G.C., Whittinghill D., Bosley K., Dietrick J. \& Lashomb J.H. 2003: Assimilation of carbon and nitrogen from pollen and nectar by a predaceous larva and its effects on growth and development. Ecol. Entomol. 28: 717-728.

Pell J., Baverstock J., Roy H.E., Ware R.L. \& Majerus M.E. 2008: Intraguild predation involving Harmonia axyridis: a review of current knowledge and future perspectives. BioControl 53: 147-168.

Pemberton R.W. \& Vandenberg N.J. 1993: Extrafloral nectar feeding by ladybird beetles (Coleoptera: Coccinellidae). Proc. Entomol. Soc. Wash. 95: 139-151.

Punt W. ET AL. 1976-2003: The Northwest European Pollen Flora (NEPF). Vols 1-8. Elsevier, Amsterdam.

Ricci C. \& Ponti L. 2005: Seasonal food of Ceratomegilla notata (Coleoptera: Coccinellidae) in mountain environments of Northern Italian Alps. Eur. J. Entomol. 102: 527-530.

Ricci C., Ponti L. \& Pires A. 2005: Migratory flight and prediapause feeding of Coccinella septempunctata (Coleoptera) adults in agricultural and mountain ecosystems of Central Italy. Eur. J. Entomol. 102: 531-538.

StataCorp. 2005: Stata Statistical Software: Release 9. StataCorp LP, College Station, TX, 423 pp.

Tedders W.L. \& Schaefer P.W. 1994: Release and establishment of Harmonia axyridis (Coleoptera: Coccinellidae) in the South-eastern United States. Entomol. News 105: 228-243.

Triltsch H. 1997: Contents in field sampled adults of Coccinella septempunctata (Col.: Coccinellidae). Entomophaga 42: 125-131.

TriLtsch H. 1999: Food remains in the guts of Coccinella septempunctata (Coleoptera: Coccinellidae) adults and larvae. Eur. J. Entomol. 96: 355-364.

Watanabe M. 2002: Cold tolerance and myo-inositol accumulation in overwintering adults of a lady beetle, Harmonia axyridis (Coleoptera: Coccinellidae). Eur. J. Entomol. 99: 5-9.

Yarbrough J.A., Armstrong J.L., Blumberg M.Z., Phillips A.E., McGahee E. \& Dolen W.K. 1999: Allergic rhinoconjunctivitis caused by Harmonia axyridis (Asian lady beetle, Japanese lady beetle, or lady bug). J. Allergy Clin. Immun. 104: 704-705. 